\title{
THE GASTRIC SECRETION IN NORMAL AND RHEUMATIC CHILDREN
}

BY

\author{
JEsSIE W. OGILVIE, B.Sc., M.B., Сн.B., D.P.H.*
}

(From the Department of Paediatrics, Glasgow University and the Biochemical Laboratory, Royal Hospital for Sick Children, Glasgow.)

The object of the present investigation was to determine whether the gastric secretion in children is influenced by certain diseases. The results obtained from gastric analyses in normal children and in those suffering from various manifestations of rheumatism are described.

\section{Gastric secretion in healthy children.}

Before considering the gastric secretion in disease it seemed advisable to determine the variations in health and to what degree these were influenced by age, for there is considerable difference of opinion on these points.

It is generally accepted that the gastric secretion is influenced by several factors such as age, general condition and psychological response of the individual, as well as by certain diseases. Although most of these conclusions have been obtained from work done on the gastric secretion in adults, several investigators have shown that they apply also to infants and young children.

Klementsson $^{1}$ states that there is an increase in acidity which reaches its maximum between four and seven years and remains about that level for the remainder of childhood; while Vanzant, Alvarez, Eusterman, Dunn and Berkson" show that there is a rapid increase up to twenty years after which the acidity decreases to old age. They also show that at puberty males have higher acidity than females and that the frequency of achlorhydria increases from youth to old age. It is a well-known fact that a certain proportion of otherwise healthy normal adults have no free hydrochloric acid, but whether this happens in children is doubtful. $\mathrm{Muhl}^{3}$, in examining forty healthy children from one to thirteen years, found none with achlorhydria and only one with hypochlorhydria. Chievitz ${ }^{4}$ also never found congenital achylia in healthy children, although in infants under one year of age the acidity was lower than in adults and older children. Klementsson ${ }^{1}$ discusses the possibility of congenital achylia and does not consider that there is any convincing evidence of its occurrence. Griswold and Shohl ${ }^{5}$ found that even in the very young infant free hydrochloric acid is present in the gastric secretion and record a $\mathrm{pH}$ value of 2.6 as early as one hour after birth.

The type of stimulus used has a very definite effect on the gastric response as some ' $\mathrm{fix}$ ' the acid more than others. It is recognized that histamine gives a maximum stimulation and has the advantage of giving a clear juice which is secreted so rapidly that duodenal regurgitation does not occur (Klumpp and Bowie ${ }^{6}$ ). Neutral 7 per cent. ethyl alcohol is also made use of by some workers but in children it has the disadvantage of not being a usual constituent of the diet. This disadvantage is pointed out by Deitrich and Shelby ${ }^{7}$ who compared the results obtained from a test meal of shredded wheat biscuits and one using 7 per cent. ethyl alcohol.

* This work was done during the tenure of a Muirhead Scholarship and a McCunn Medical Research Scholarship. 
Although Wills and Paterson ${ }^{8}$ found that with various types of milk feeds there was an increase in gastric acidity with those of high buffer value they concluded that the response depended more on the general condition of the child than on the nature of the feed. They also showed that the gastric juice of breast-fed infants had a higher $\mathrm{pH}$ and that the stomach emptied more quickly than in those artificially fed. That the milk content of the previous diet has no influence on the gastric secretion was shown by Chievitz'.

The question of the effect of duodenal regurgitation on the gastric acidity has given rise to many conflicting statements. Davison ${ }^{9}$ has shown that only about onethird of all specimens in children are free of either salivary or duodenal contamination. Morrell Roberts ${ }^{10}$ considers that regurgitation is normal in man and takes as evidence of its occurrence a fall in acidity with a corresponding rise in inorganic chlorine and little or no change in the total chlorine and considers that any difference is due to dilution only. Bolton ${ }^{11}$ also holds that regurgitation is a normal occurrence and that defective neutralization may be due to insufficient relaxation of the pylorus.

On the other hand Shay, Katz and Schloss ${ }^{12}$ consider that the duodenal contents are never sufficiently alkaline to affect the gastric acidity to any great extent and that indeed the pancreas would have difficulty in secreting such a quantity. McLean and Griffiths ${ }^{13}$ think that the gastric acidity is regulated by the concentration of acid and that if regurgitation occurred there would be an increase in the amount of trypsin and in the $\mathrm{CO}_{2}$ content of the gastric contents which is only the case when bile is present. Indeed they, with Williams ${ }^{14}$, find in isolated gastric pouches in dogs that the acidity varies as in the normal stomach. Copeman and Hill $^{15}$ have studied the analyses of fractional test meals in fifty normal children and find that, whereas free and total acid varied considerably, even in the same indrvidual, the total chlorine was much more constant, and therefore is a better index of the gastric secretion. They therefore suggest that a modified curve could be obtained by omitting the initial fall due to the ingestion of food and plotting the fasting and hourly values for the total chlorine, and that this curve would give a very good indication of gastric secretion and would obviate the fallacies of the presence of saliva and of duodenal regurgitation. The acidity of a sample depends on the level at which it is obtained, and it follows that any regurgitation will affect the acidity at the pyloric end of the stomach, while it may have little or no effect on the total amount of juice. Duthie ${ }^{16}$ has shown that there is an appreciable difference in the acidity of the juice obtained from the pyloric portion and that obtained from the cardiac. He found that the greatest difference was present when bile was obtained from the pyloric tube, showing that regurgitation had occurred. If the tube is kept at the same level throughout the test, this should have little effect on the changes during digestion. Ylppo ${ }^{17}$ found that by producing fever with hot baths, etc., the gastric acidity is lower than normal. Fever produced by injection of foreign protein. causes a fall in gastric acidity for as long as the fever lasts. He suggests that this may have a connection with summer diarrhoea and the gastro-intestinal symptoms at the commencement of any acute parenteral injection.

Present investigation.--An attempt has been made to determine the effect of age on the gastric secretion of healthy children. As the children were all in the Sick Children's Hospital the number of healthy individuals was comparatively small. They were all convalescent from the diseases with which they had been admitted to hospital and were generally tested just prior to discharge.

The examinations were carried out in the morning after the night's fast, and blood was taken before the test meal was given. The fasting gastric juice was then removed by means of a fine Ryle's tube and strained porridge given in amounts varying with age. Thereafter samples were withdrawn every 15 minutes for 2 hours, except in young children who would not retain the tube, and in these, samples were removed every half hour. The samples of gastric contents were then centrifugalized 
and the supernatant fluid examined. Free and total acidity were estimated by titration with : $\mathrm{NaOH}$, using dimethylaminobenzol and phenolphthalein as indicators. A modification of Van Slyke's method was used to determine the chlorine of the gastric juice and of the blood. An index of the peptic activity was obtained by measuring in millimetres the amount of egg white digested in Mett's tubes after incubation for 24 hours at $37^{\circ} \mathrm{C}$. In some of the later cases the $\mathrm{pH}$ of each specimen was estimated by means of the B.D.II. capillator apparatus. (ases with a very high or very low acidity were generally re-examined and if achlorhydria was still found an injection of $0 \cdot 15-0 \cdot 28$ c.c. of $1 / 1000$ histamine phosphate was given. The iodinestarch reaction was used as an indication of the time at which the stomach was empty of porridge.

Owing to the wide individual variations in the acidity of the gastric contents the patients were divided into age periods each of three years and the average maximum values obtained and compared. The results are given in table 1. From this and fig. 1 it will be seen that there is an increase in

TABLE 1.

Gastric analyses of Normal cases.

\begin{tabular}{|c|c|c|c|c|c|c|c|c|c|}
\hline $\begin{array}{l}\text { Age in } \\
\text { years. }\end{array}$ & $\begin{array}{c}\text { No. of } \\
\text { cases }\end{array}$ & $\begin{array}{r}\text { Free } \\
\text { HCl } \\
\text { c.c. } \underset{1}{*}\end{array}$ & $\begin{array}{l}\text { Total } \\
\text { acidity } \\
\text { c.c. }\end{array}$ & $\begin{array}{c}\text { Total } \\
\text { chlorine } \\
\text { (.c. }\end{array}$ & $\begin{array}{c}\text { Peptic } \\
\text { activity } \\
\text { units. }\end{array}$ & age groo & Inx. & $\begin{array}{c}\text { No. } \\
\text { of } \\
\text { cases }\end{array}$ & $\begin{array}{c}\text { Total } \\
\text { chlorine of } \\
\text { fasting bloor } \\
\text { rec. }\end{array}$ \\
\hline $0-3$ & 12 & $2 \cdot 2 \cdot 7$ & $+3 \cdot 9$ & $75 \cdot 9$ & $\pi 1 \cdot 1 \quad(9)^{*}$ & $4 \cdot 2$ & $2 \cdot 2$ & 21 & $7: 7$ \\
\hline $3-6$ & 19 & $30 \cdot 0$ & $46 \cdot 0$ & $7 a \cdot 2$ & $45 \cdot 1(11)^{*}$ & $3 \cdot 5$ & $2 \cdot 0$ & $1 \because$ & $73 \cdot 7$ \\
\hline $6-9$ & 15 & $31 \cdot 4$ & $5(1) 7$ & 771 & $: 32 \cdot 4(1)^{*}$ & $3 \cdot 0$ & $2 *$ & 15 & $73 \cdot 9$ \\
\hline $9-12$ & 14 & $41 \cdot 0$ & $60 .+$ & $5 \%$ & $\ldots$ & - & & 14 & $73 \cdot 1$ \\
\hline
\end{tabular}

* Figures in brackets indicate number of cases.

Free $\mathrm{HCl}$.

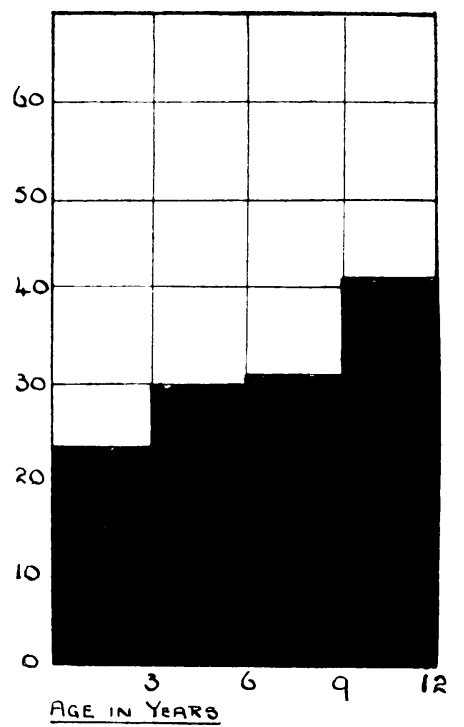

Total acidity.

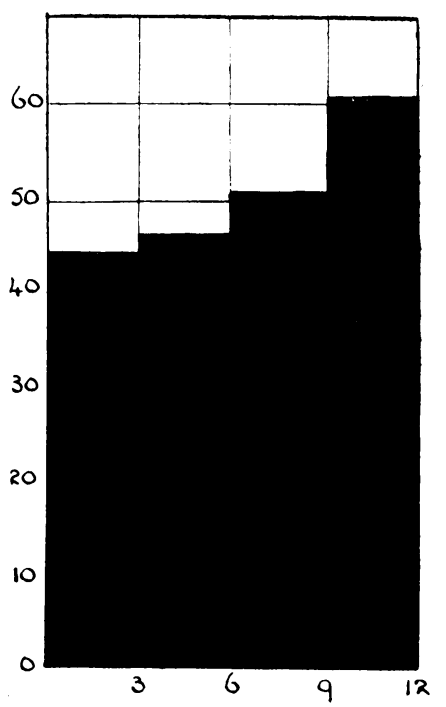

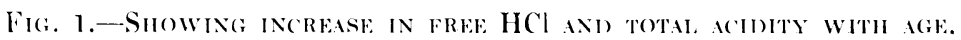


the average maximum free and total acidity with age. This is statistically significant when non-adjacent groups are compared but is not apparent when adjacent groups are examined. The $\mathrm{pH}$ of the fasting juice also showed an increase with age, while the average maximum $\mathrm{pH}$ showed no significant difference in various age periods.

The total chlorine of the gastric juice also showed an increase with age but this is only significant when the youngest and oldest groups are compared.

The peptic activity was very variable. Twenty-one children were tested and in eight ( 38 per cent.) the curve for peptic activity ran parallel with the total acidity curve, while in five (23.8 per cent.) it followed the curve for inorganic chlorine. In the remainder it appeared to be independent of any of the other curves. The time at which the maximum activity occurred varied but in eight ( 38 per cent.) it was highest in the fasting specimen and in four (19 per cent.) at two hours. This is in agreement with McLean, Griffiths and Hughes $^{18}$ who have shown that peptic activity increased towards the end of secretion and is generally highest in the resting juice. In several cases of the present series the peptic activity curves showed more than one peak.

After this summary of the results of the gastric analyses the individual cases may be studied more particularly. In all, 60 were examined, 38 being girls and 22 boys, their ages ranging from 5 months to $12 \frac{1}{4}$ years. The free and total acidity generally ran parallel to each other, while the total chlorine. after the initial fall on the ingestion of the meal, rose to a fairly constant figure, following the acidity but at a higher level. When the acidity fell due to excess of mucus or the presence of bile, the total chlorine generally remained high but if the fall in acidity was due to lack of secretion the chlorine fell also. Eight cases (13 per cent.) had hyperchlorhydria having more than 50 per cent. free $\mathbf{H C l}$ in terms of $\frac{\sim}{i}$ alkali. Two cases showed hypochlorhydria having less than 12 per cent. free acid; one case had achlorhydria when first tested but on being retested a week later the free acid was found to reach a maximum of $20 \cdot 3$ per cent. Fifty children ( 82 per cent.), therefore, had gastric acidity within normal limits taking $20-40$ per cent. as normal for free acid ; 40-60 per cent. for total acidity in terms of $\underset{T}{\mathrm{r}}$ alkali and 60-90 millieq. per litre for total chlorine.

The emptying time was determined by the starch-iodine reaction and in the normal cases 63 per cent. gave a negative reaction at two hours, while 37 per cent. still gave a blue colour with iodine in the two hours specimen. If anything the emptying time was shorter in boys than in girls.

From table 1 it will be seen that the average total chlorine of the blood is constant for all the age groups. The total chlorine of the blood and fasting gastric juice tend in most cases to be in about the same concentration: in some, however, the blood chlorine was high when the gastric chlorine was low and vice versa. In a series of twenty other children the total chlorine of the fasting blood was compared with that of blood taken forty-five minutes after a test meal and there was found to be practically no difference.

The results found in normal children show that with age there is a definite increase in the acidity and total chlorine of the oastric secretion 
and that this is evident up to 12 years of age. The peptic activity appears to be higher in the younger children but the numbers are too small for satisfactory comparison. Duodenal regurgitation did not appear to occur except when the stomach was almost empty or when there was severe retching.

\section{Gastric analysis in rheumatic conditions.}

The recent view that the manifestations of rheumatism have an allergic basis suggested that a study of the gastric secretion in patients suffering from this disease might show some departure from normal similar to that found in recognized allergic conditions.

Bray ${ }^{19}$ has shown in his recent work on the allergic child that in asthma and similar conditions there is an increase in the frequency of hypochlorhydria and achlorhydria compared with normal. In discussing the possible allergic explanation of the rheumatic syndrome he mentions the chronic arthritis often seen in individuals with other allergic phenomena and likens it to a giant urticaria. He quotes Poynton and Schlesinger ${ }^{20}$ who show by analogy, experiment and clinical evidence that rheumatism is similar in its manifestations to other allergic conditions. They also mention the low gastric acidity which is obtained in cases of chronic arthritis.

If this hypothesis is correct one would expect to find a higher percentage of cases with hypochlorhydria and achlorhydria among those with rheumatism than among non-rheumatic subjects. To test this the gastric secretion of a series of patients with manifestations of acute rheumatism was examined and compared with results obtained from the group of children of the same age described in the previous section.

All the children examined were afebrile and convalescent, especially those with chorea and all were over three years except one of two years and nine months who for convenience was included in the youngest group. The average maximum figures over periods of three years were taken as in the first part of this paper.

Ninety-nine children were examined, 68 girls and 31 boys and the figures obtained are shown in Table 2. It will be seen that in the three-six years

TABLE 2.

Gastric analyses of Rheumatic cases.

\begin{tabular}{|c|c|c|c|c|c|c|c|}
\hline \multirow{2}{*}{$\begin{array}{l}\text { Age in } \\
\text { years. }\end{array}$} & \multirow{2}{*}{$\begin{array}{l}\text { No. of } \\
\text { cases. }\end{array}$} & \multicolumn{4}{|c|}{$\begin{array}{l}\text { Averages of maximal values in each } \\
\text { age group. }\end{array}$} & \multirow[b]{2}{*}{$\begin{array}{c}\text { No. of } \\
\text { cases }\end{array}$} & \multirow{2}{*}{$\begin{array}{c}\text { Total } \\
\text { chlorine of } \\
\text { fasting blood } \\
\text { c.c. } \mathrm{N}\end{array}$} \\
\hline & & $\begin{array}{l}\text { Free } \\
\text { HCl } \\
\text { c.c. } \frac{N}{1 \sigma}\end{array}$ & $\begin{array}{c}\text { Total } \\
\text { acidity } \\
\text { c.c. } \mathrm{N} \text { To }\end{array}$ & $\begin{array}{l}\text { Total } \\
\text { chlorine } \\
\text { c.c. } \frac{N}{10}\end{array}$ & $\begin{array}{c}\text { Peptic } \\
\text { activity } \\
\text { units. }\end{array}$ & & \\
\hline $0-3$ & - & - & - & - & - & - & - \\
\hline $3-6$ & 12 & $23 \cdot 5$ & $43 \cdot 9$ & $70-7$ & $102.4(1)^{*}$ & 12 & $75 \cdot 1$ \\
\hline $6-9$ & 36 & $37 \cdot 6$ & $55 \cdot 6$ & $85 \cdot 4$ & $69 \cdot 2(11)^{*}$ & 38 & $74 \cdot 9$ \\
\hline $9-12$ & 51 & $43 \cdot 8$ & $60 \cdot 0$ & $79 \cdot 2$ & $90.9(17)^{*}$ & 58 & $69 \cdot 9$ \\
\hline
\end{tabular}

* Figures in brackets indicate number of cases. 
period the average maximum for free and total acid and total chlorine is lower in the rheumatic than in the normal cases, while over six years the figures are higher in rheumatism. The differences are small and not statistically significant.

The peptic activity appears to be higher in the rheumatic group but the numbers are too small for comparison.

The average total chlorine of the fasting blood is similar to the normal in each age period.

Examining the results in more detail 24 patients were found to have hyperchlorhydria; that is 24 per cent. as compared with 13 per cent. of the normals. Of these, 15 were girls and 9 were boys; 15 were cases of chorea (6 with cardiac disease) and 9 of rheumatic fever ( 8 with cardiac disease). Hypochlorhydria was present in seven of the rheumatic cases and all were girls, six with chorea and one with rheumatism. Five cases had achlorhydria, three boys and two girls. Two of the boys had chorea and one rheumatism, while one girl had chorea and one rheumatism. One of the boys on being retested was found to have free acid but low in amount, another on a second test had a fair quantity. The girl with chorea gave a normal histamine response. The girl with rheumatism was retested after tonsillectomy and she was found to have $23 \cdot 4$ per cent. free hydrochloric acid. The boy with rheumatism appeared to have a complete achylia; in six test meals over a period of six months no free acid was found and the total acidity, the chlorine and the peptic activity were low even with histamine. Ventriculin and large doses of iron improved his mild anaemia and general condition without having any effect on his gastric secretion.

The remaining 63 cases (63 per cent.) were within average limits as against 82 per cent. of the normals, so that although there is no significant difference in the average figures for gastric secretion of rheumatic and normal children the former show more variation with a larger number of extremes (table 3).

\section{TABLE 3.}

The incidence of abNormal gastric SECretion in healthy aNd RHEUMatic ChILDREN. Percentage of total.

$\begin{array}{lccccc} & \begin{array}{c}\text { Within } \\ \text { normal limits. }\end{array} & \begin{array}{c}\text { Hyper- } \\ \text { chlorhydria. }\end{array} & \begin{array}{c}\text { Hypo- } \\ \text { chlorhydria. }\end{array} & \text { Achlorhydria. } \\ \text { Normal }(60 \text { cases }) & \ldots & 82 & 13 & 5 & 0 \\ \text { Rheumatic }(99 \text { cases }) \ldots & 64 & 24 & 11 & 1\end{array}$

The emptying time was much the same as for normal children; 35 per cent. showed a starch reaction at two hours while in 65 per cent. starch could not be detected at this period. As in the non-rheumatic cases boys showed a more rapid emptying rate than girls, but a much larger number of the latter were tested.

Fifty-one of the rheumatic cases were skin tested with antigen prepared from streptococci (haemolytic and non-haemolytic). The bacterial extracts were made according to the method employed by Collis ${ }^{21}$. It was found that 
seven of the forty-one children sensitive to streptococci had hyperchlorhydria, three had hypochlorhydria and four achlorhydria but no connection was discovered between the severity of the skin reaction and the gastric response. One boy with normal gastric secretion, who had a sharp reaction with tachycardia and adenitis twenty-four hours after the skin test, was given another test meal at that time, that is when presumably he was having an allergic reaction. The gastric analysis gave practically identical results to those found previously. Of thirteen non-rheumatic children who reacted to streptococcal antigen, one had hyperchlorhydria and the others had a gastric secretion within normal limits.

A review of the results obtained in the rheumatic patients shows that 12 per cent. had either hypochlorhydria or achlorhydria against 5 per cent. of the normal. This suggests that there may be an allergic factor associated with acute rheumatism in childhood. There seems to be no connection between the severity of the skin reaction to streptococcal antigen and the type of gastric analysis obtained.

I desire to thank Professor G. B. Fleming and Dr. N. Morris for suggesting this investigation and for their helpful criticism. I also wish to acknowledge the gift by Messrs. Parke, Davis \& Co. of the histamine phosphate used in the cases referred to in this paper.

\section{REFERENCES.}

1. Klementsson, E., Acta Paed., Uppsala, 1923-24, III, 136.

2. Vanzant, F. R., Alvarez, W. C., Eusterman, G. B., Dunn, H. L., \& Berkson, J., Arch. Int. Med., Chicago, 1932, XLIX, 345.

3. Muhl, G., Acta Paed., Uppsala, 1925, IV, 356.

4. Chievitz, I., ibid., 1922, I, 416.

5. Griswold, C., \& Shohl, A. T., Am. J. Dis. Child., Chicago, 1925, XXX, 541.

6. Klumpp, T. G., \& Bowie, M. A., J. Clin. Invest., New York, 1933, XII, 1.

7. Deitrich, H., \& Shelby, D. C., Am. J. Dis. Child., Chicago, 1931, XLI, 1086.

8. Wills, L., \& Paterson, D., Arch. Dis. Child., London, 1926, I, 232.

9. Davison, W. C., Am. J. Dis. Child., Chicago, 1925, XXX, 23.

10. Roberts, W. M., Quart. J. Med., Oxford, 1925-26, XIX, 74.

11. Bolton, C., Brit. Med. J., London, 1923, ii, 269.

12. Shay, H., Katz, A. B., \& Schloss, E. M., Arch. Int. Med., Chicago, 1932, L, 605.

13. McLean, H., \& Griffiths, W. J., J. Physiol., London, 1928, LXV, 63.

14. McLean, H., Griffiths, W. J., \& Williams, B. W., loc cit., 77.

15. Copeman, W. S. C., \& Hill, N. G., Quart. J. Med., Oxford, 1928, XXII, 33.

16. Duthie, R., ibid, 1926-27, XX, 265.

17. Ylppo, A., Acta Paed., Uppsala, 1924, III, 216.

18. McLean, H., Griffiths, W. J., \& Hughes, T. A., J. Physiol., London, 1929, LXVII, 409.

19. Bray, G. W., Recent Advances in Allergy, London, 1931, 165, 363 and 393.

20. Poynton, F. J., \& Schlesinger, B., Recent Advances in the Study of Rheumatism, London, 1931.

21. Collis, W. R. F., Lancet, London, 1931, i, 1341. 